\title{
Carbapenemase-producing Klebsiella pneumoniae in the Czech Republic in 2011
}

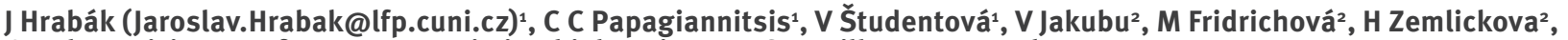

Czech Participants of European Antimicrobial Resistance Surveillance Network ${ }^{3}$

1. Department of Microbiology, Faculty of Medicine and University Hospital in Plzeň, Charles University in Prague, Plzeň, Czech Republic

2. National Reference Laboratory for Antibiotics, National Institute for Health, Prague, Czech Republic

3. The members of the network are listed at the end of the article

Hrabák J, Papagiannitsis CC, Študentová V, Jakubu V, Fridrichová M, Zemlickova H, Czech Participants of European Antimicrobial Resistance Surveillance

Network. Carbapenemase-producing Klebsiella pneumoniae in the Czech Republic in 2011. Euro Surveill. 2013;18(45):pii=20626. Available online: http://www.

eurosurveillance.org/ViewArticle.aspx?Articleld=20626

Carbapenemase-producing Enterobacteriaceae and Pseudomonas spp. are increasingly reported in many countries all over the world. Due to the resistance of those bacteria to almost all antibiotics (e.g. beta-lactams, aminoglycosides, fluoroquinolones), treatment options are seriously limited. In the Czech Republic, the incidence of carbapenemase-producing Enterobacteriaceae seems to be low, restricted to only three cases detected between 2009 and 2010. Here, we describe molecular typing of 15 carbapenemase-producing Klebsiella pneumoniae isolates identified in the Czech Republic during 2011. Five VIM1-producing isolates belonging to sequence type (ST) 11 and one VIM-4-producing isolate of ST1029 have been detected. bla $a_{\mathrm{VIM}-1}$ and $b a_{\mathrm{VIM}-4}$ as a part of class 1 integrons were chromosomally located or carried by a plasmid belonging to $\mathrm{A} / \mathrm{C}$ replicon type $\left(b / a_{\mathrm{VIM}-4}\right)$. KPC-3-producing isolates of $\mathrm{ST}_{512}$, recovered from six patients, caused an outbreak. Three more isolates producing KPC-2 enzyme belonged to ST258. Both $b l a_{\text {KPC }}$ genes were part of the Tn $4401 a$ transposon carried on plasmids of the pKpQIL type. The isolates were resistant to all antibiotics tested except colistin and/or gentamicin. Four of these 15 strains were recovered from patients repatriated to the Czech Republic from Greece and Italy. This is the first report of outbreaks caused by carbapenemase-producing Enterobacteriaceae in the Czech Republic.

\section{Introduction}

Spread of carbapenemase-producing Enterobacteriaceae and Pseudomonas spp. has been observed in many countries across the world [1-3]. Carbapenemase producers are usually resistant to almost all of the effective antibiotics (such as betalactams, aminoglycosides, fluoroquinolones). Therapy of infections caused by such bacteria is limited to few choices (such as colistin and/or a combination therapy) with unpredictable effect [4]. Therefore, prevention of their spread in healthcare settings and in the community is a big challenge for medicine today.

In the Czech Republic, occurrence of carbapenemaseproducing bacteria seemed to be rare with only sporadic cases of carbapenemase-producing Klebsiella pneumoniae (VIM-1, KPC-2), Serratia marcescens (VIM-1) and metallo-beta-lactamase-producing Pseudomonas aeruginosa (VIM-2, IMP-7) [1,5-7]. In 2011, however, the incidence of such bacteria increased, especially in $K$. pneumoniae and $P$. aeruginosa. The aim of this study was to analyse carbapenemase-producing $K$. pneumoniae isolates recovered from Czech hospitals in 2011.

\section{Methods}

Bacterial isolates, identification and susceptibility testing In 2011, a total of 102 Enterobacteriaceae isolates, nonsusceptible to carbapenems according to the European Committee on Antimicrobial Susceptibility Testing (EUCAST) guidelines [8], were sent to the Czech national reference laboratory (NRL) for Antibiotics from local microbiology laboratories, for verification of carbapenemase production. All isolates were tested for carbapenemase production by MALDI-TOF mass spectrometry (MS) meropenem hydrolysis assay [9,10]. Phenotypic identification of carbapenemases was performed by an inhibitor-based method [11]. Species identification was performed using a MALDI Biotyper Version 3.0 (Bruker Daltonik GmbH., Bremen, Germany). Minimum inhibitory concentrations (MICs) to 12 antibiotics (piperacillin, piperacillin/tazobactam, cefotaxime, ceftazidime, cefepime, meropenem, ciprofloxacin, gentamicin, amikacin, colistine, chloramphenicol, trimethoprim/ sulfamethoxazole) were determined according to the EUCAST recommendations [12]. 
TABLE 1

Characterisation of VIM-1-producing Klebsiella pneumoniae isolates recovered from Czech hospitals in 2011 ( $\mathrm{n}=6$ )

\begin{tabular}{|c|c|c|c|c|c|c|c|}
\hline $\begin{array}{l}\text { Strain } \\
\text { number }\end{array}$ & $\begin{array}{l}\text { Isolation } \\
\text { date }\end{array}$ & Hospital & ST & Conjugation & Replicon type & Gene cassettes & Notes \\
\hline$V_{554}$ & 1 Sep & $\mathrm{A}_{5}$ & 11 & - & - & $a a c\left(6^{\prime}\right)-l b, b l a_{\mathrm{VIM}-1}$ & \\
\hline$V_{555}$ & 24 Aug & $\mathrm{A}_{5}$ & 11 & - & - & $a a c\left(6^{\prime}\right)-I b, b l a_{\mathrm{VIM}-1}$ & \\
\hline$v_{5} 64$ & 26 May & $\mathrm{A}_{5}$ & 11 & - & - & $a a c\left(6^{\prime}\right)-l b, b l a_{\mathrm{VIM}-1}$ & \\
\hline V602 & 10 Oct & $\mathrm{A}_{5}$ & 11 & - & - & $a a c\left(6^{\prime}\right)-I b, b l a_{\mathrm{VIM}-1}$ & \\
\hline V633 & $210 c t$ & $\mathrm{~A}_{5}$ & 11 & - & - & $a a c\left(6^{\prime}\right)-l b, b l a_{\mathrm{VIM}-1}$ & \\
\hline V624 & 17 Oct & NJ & 1029 & + & $A / C$ & bla $_{\text {VIM-4 }}$ & Import from Greece \\
\hline
\end{tabular}

ST: sequence type.

Typing

All isolates were typed by pulsed-field gel electrophoresis (PFGE) [13] using the restriction enzyme Xbal; the results were interpreted according to Tenover et al. [14]. All isolates were also subjected to multilocus sequence typing (MLST) as described previously [15]. The database available at www.pasteur.fr/recherche/ genopole/PF8/mlst/Kpneumoniae.html was used for assigning sequence types (STs).

Beta-lactamase identification, bla gene environment mapping

Detection of bla genes, encoding important carbapenemase types, was performed by PCR using specific primers for $b a_{0 \times A-48}, b l a_{I M P}, b l a_{\mathrm{NDM}}, b l a_{\mathrm{VIM}}$ and $b l a_{\mathrm{KPC}}$ [2,16-18]. The gene environment of bla $a_{\mathrm{KPC}}$ was determined by PCR mapping as proposed by Naas et al. [17]. Mapping of the VIM-encoding integrons was performed by PCR [16]. For detection of bla $a_{\mathrm{CMY}}$-type genes, a PCR assay was employed [19]. PCR products were sequenced on both strands.

\section{Conjugation and transformation}

To check transferability of the resistance genes on a conjugative plasmid, conjugal transfer was carried out by broth mating, using rifampin-resistant Escherichia coli $\mathrm{A} 15$ as previously described [20]. Transconjugants were selected with $50 \mathrm{mg} / \mathrm{L}$ ampicillin and $60 \mathrm{mg} / \mathrm{L}$ rifampin. Transformation experiments were performed with plasmid extracts, purified using a Qiagen Plasmid Maxi Kit (Qiagen GmbH, Hilden, Germany), and E. coli DH5alpha chemically competent cells as a recipient. Transformants were selected with $50 \mathrm{mg} / \mathrm{L}$ ampicillin.

\section{Plasmid analysis}

Plasmid content was visualised after S1 linearisation followed by PFGE separation [21]. Localisation of blavim, $b l a_{\mathrm{KPC}}$ and $b a_{\mathrm{CMY}}$ genes was analysed by hybridisation. The bla-specific probes were prepared from PCR amplicons using a BrightStar Psoralen-Biotin kit (Applied Biosystems, Prague, Czech Republic). DNA after S1 linearisation and PFGE separation was transferred on BrightStar-Plus Positively Charged Nylon Membrane
(Applied Biosystems, Prague, Czech Republic) according to manufacturer recommendations, and hybridised for $24 \mathrm{~h}$ at $42{ }^{\circ} \mathrm{C}$. Detection of membranes was performed by BrightStar BioDetect Kit (Applied Biosystems, Prague, Czech Republic). PCR-based replicon typing (PBRT) of plasmids was performed as proposed by Carattoli et al. [22], using total DNA from transconjugants/transformants or from clinical isolates that were non-successful in conjugation and transformation experiments. IncF plasmids were further characterised by replicon sequence typing (RST) [23]. Plasmids carrying bla $a_{\mathrm{KPC}}$ were identified by PCR mapping as proposed by Baraniak et al. [24].

\section{Results}

MALDI-TOF MS meropenem hydrolysis assay confirmed carbapenemase activity in 15 of the 102 isolates analysed. Ethylene-diamine tetra-acetic acid (EDTA)-meropenem combined disk test confirmed metallo-beta-lactamase production in six of the isolates. The respective aminophenylboronic acid-meropenem test was positive for KPC production in the remaining nine isolates. All of the suspected isolates based on the phenotypic tests were positive in MALDI-TOF MS meropenem hydrolysis assay.

\section{VIM-producing isolates}

Five of the six VIM-1-producing $K$. pneumoniae were isolated from one hospital $\left(A_{5}\right)$ in Prague (Table 1). In all five isolates, MICs of meropenem were in the susceptible category according to the EUCAST criteria, ranging from 1 to $2 \mathrm{mg} / \mathrm{L}$. The five isolates were resistant to all antibiotics tested, except colistin. The variable region of their class 1 integron containing bla $a_{\mathrm{VIM}-1}$ gene is described in Table 1. Neither transconjugants nor transformants were obtained from any of the five isolates detected in hospital $\mathrm{A}_{5}$. A bla $_{\mathrm{vIM}}$-specific probe hybridised strongly with a band corresponding to the chromosomal material, which confirmed the chromosomal location of the bla $a_{\text {VIM-1 }}$-containing integron. All isolates belonged to $\mathrm{ST}_{11}$, which is a common clone of $K$. pneumoniae that possesses extended spectrum (ESBL)- and AmpC-beta-lactamases [25,26]. 
TABLE 2

Characterisation of KPC-producing Klebsiella pneumoniae isolates recovered from Czech hospitals in 2011 (n=9)

\begin{tabular}{|c|c|c|c|c|c|}
\hline Strain number & Isolation date & Hospital & ST & KPC type & Notes \\
\hline$V_{514}$ & $13 \mathrm{Jul}$ & $A_{41}$ & $\mathrm{ST}_{512}$ & $\mathrm{KPC}-3$ & Import from Italy, index case \\
\hline$v_{556}$ & 18 Aug & A41 & $\mathrm{ST}_{512}$ & $\mathrm{KPC}-3$ & \\
\hline$v_{557}$ & 18 Aug & A41 & $\mathrm{ST}_{512}$ & $\mathrm{KPC}-3$ & \\
\hline$V_{573}$ & 8 Aug & A41 & $\mathrm{ST}_{512}$ & KPC-3 & \\
\hline V646 & 14 Nov & A41 & $\mathrm{ST}_{512}$ & KPC-3 & \\
\hline$V_{719}$ & $28 \mathrm{Dec}$ & A41 & $\mathrm{ST}_{512}$ & KPC-3 & \\
\hline$V_{597}$ & $4 \mathrm{Oct}$ & A6 & $\mathrm{ST} 258$ & $\mathrm{KPC}-2$ & Import from Greece, index case \\
\hline V640 & $7 \mathrm{Nov}$ & A6 & $\mathrm{ST} 258$ & $\mathrm{KPC}-2$ & \\
\hline V601 & 21 Oct & $A_{51}$ & $\mathrm{ST} 258$ & KPC-2 & Import from Greece \\
\hline
\end{tabular}

ST: sequence type.

The sixth VIM-4-producing strain was detected in October 2011 in a patient admitted to the hospital in the Czech Republic after the medically assisted repatriation from a hospital in Northern Greece. Carbapenemresistant $K$. pneumoniae (isolate no. V624; Table 1) was isolated from blood immediately after the admission to the hospital. The isolate belonged to ST1029, a novel sequence type, which is a single locus variant (SLV) of ST383 and was first reported in Greece in 2009 [19]. The strain produced VIM-4 and CMY-4 beta-lactamases as described in $\mathrm{ST}_{3} 83$ by Papagiannitsis et al. [19]. However, no production of KPC enzyme was identified in our strain, contrary to the Greek strain. The class 1 integron consisting of a sole $b a_{\mathrm{VIM}-4}$ gene cassette was harboured by a conjugative plasmid of $A / C$ replicon type. A similar plasmid harbouring bla $a_{\mathrm{VIM}-1}$ was described by Samuelsen et al. in a patient repatriated from Greece in 2005 [27]. Immediately after the isolation of the carbapenem-resistant $K$. pneumoniae isolate, recommended isolation precautions were set up in the hospital and no transfer of the strain to another patient was found.

\section{KPC-producing isolates}

In the Czech Republic, the first KPC-producing K. pneumoniae isolate was obtained from a patient repatriated from a hospital in Italy to hospital A41 in Prague in July 2011. A carbapenem-resistant isolate producing KPC-3 was cultivated from a urine sample (isolate no. $\mathrm{V}_{514}$; Table 2). From August till December, five more KPC-3producing $K$. pneumoniae strains were identified in different patients. Their molecular and epidemiological characteristics are summarised in Table 2. Three of these patients were hospitalised on the same ward as, but without direct contact to, the index case, while the remaining two patients were hospitalised in the same time period but in different hospital wards (Figure 1).

Another KPC-producing isolate was recovered from a patient repatriated from a hospital on Greece to hospital A6 in Prague (isolate no. V597; Table 2). The strain was recovered from a blood sample. A second patient (isolate no. V640; Table 2) hospitalised in the same room as the previous one, was colonised with a strain of the same PFGE pattern and ST.

\section{FIGURE 1}

Timeline of successive hospital outbreaks of KPC-producing Klebsiella pneumoniae isolates in Hospital A41, Czech Republic, $2011(n=6)$

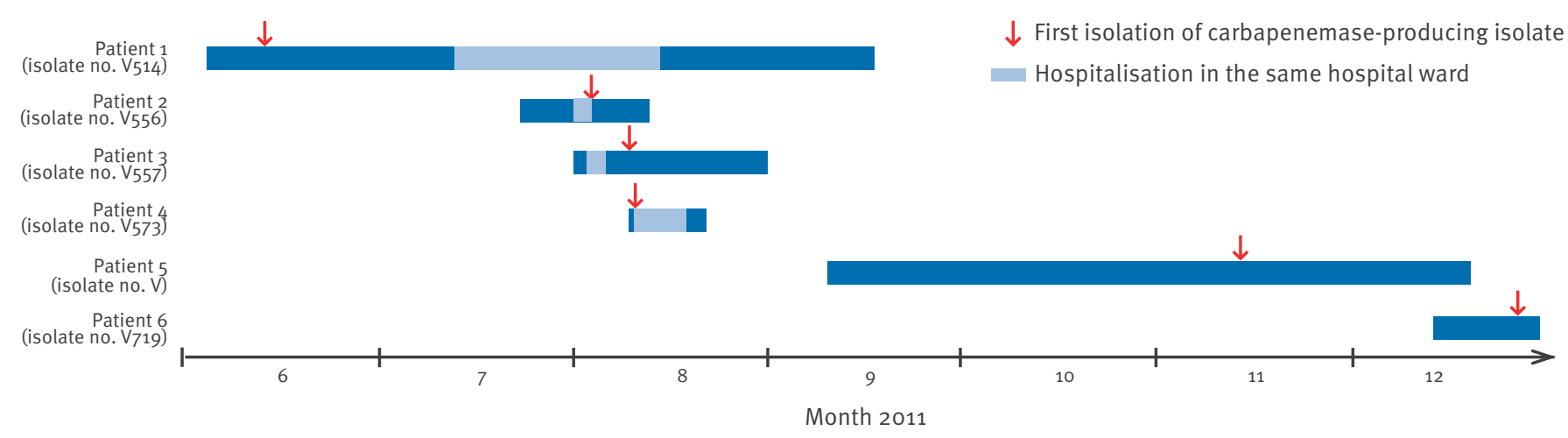


Susceptibility of carbapenemase-producing Klebsiella pneumoniae and their transconjugants/transformants, Czech Republic, $2011(n=7)$

\begin{tabular}{|c|c|c|c|c|c|c|c|c|c|c|c|c|c|c|}
\hline \multirow{2}{*}{$\begin{array}{l}\text { Strain } \\
\text { number }\end{array}$} & \multirow{2}{*}{ Species } & \multirow{2}{*}{$\begin{array}{c}\text { Beta- } \\
\text { lactamase }\end{array}$} & \multicolumn{12}{|c|}{ MICs [mg/L] } \\
\hline & & & PIP & TZP & CTX & CAZ & FEP & CIP & MEM & GEN & AMK & CST & $\mathrm{CHL}$ & SXT \\
\hline$v_{554}$ & K. pneumoniae & VIM-1 & $>64$ & $>64$ & 18 & 32 & $>16$ & 18 & 1 & $>16$ & 16 & $<0,25$ & 132 & 16 \\
\hline V624 & K. pneumoniae & VIM-4 & $>64$ & $>64$ & 18 & 32 & 8 & 18 & 8 & 0,5 & 8 & $<0,25$ & 132 & 132 \\
\hline CONJ V624 $4^{a}$ & Escherichia coli & VIM-4 & $>64$ & $>64$ & 18 & 32 & 4 & 0,125 & 2 & 0,25 & 2 & $<0,25$ & 132 & 132 \\
\hline$V_{514}$ & K. pneumoniae & KPC-3 & $>64$ & $>64$ & $>8$ & 32 & 216 & 18 & $>16$ & 1 & 32 & 8 & 132 & 232 \\
\hline$V_{597}$ & K. pneumoniae & KPC-2 & $>64$ & $>64$ & 18 & 32 & $>16$ & $>8$ & 16 & 1 & 32 & 16 & 132 & 132 \\
\hline TRAN V $597^{b}$ & E. coli & KPC-2 & $>64$ & 264 & 1 & 2 & 2 & 0,125 & 0,5 & $<0,125$ & $<0,5$ & $<0,25$ & 8 & 0,5 \\
\hline V601 & K. pneumoniae & KPC-2 & $>64$ & $>64$ & 18 & 32 & $>16$ & $>8$ & 8 & 1 & 32 & 16 & 132 & 132 \\
\hline
\end{tabular}

AMK: amikacin; CAZ: ceftazidime; CHL: chloramphenicol; CIP: ciprofloxacin; CST: colistin; CTX: cefotaxime; FEP: cefepime; GEN: gentamicin; MEM: meropenem; MIC: minimum inhibitory concentration; PIP: piperacillin; SXT: trimethoprim/sulfamethoxazole;TZP: piperacillin with tazobactam.

a CONJ V624: transconjugant of the strain no V624.

b TRAN V597: transformant of $V_{597 .}$

As the MICs of isolates of the same clone were similar, we show in the Table only representative isolates of each clone and their transformant/ transconjugant.

The last case was detected in hospital $A_{51}$ in Prague. This strain (isolate no. V601; Table 2) was obtained from the respiratory tract of a patient repatriated from a hospital on Crete (Greece). No spread to other patients was detected. No difference was detected in the PFGE patterns of ST258 and ST512 isolates.

According to the EUCAST criteria, the detected KPCproducing isolates were susceptible only to gentamicin (Table 3). MICs of colistin, which is sometimes the drug of the last choice in carbapenemase-producing Enterobacteriaceae infections, were in the resistant category $(8-16 \mathrm{mg} / \mathrm{L})$. Plasmid profiling with $\mathrm{S}_{1}$ linearisation of all clinical isolates showed a common profile with plasmids approximately 40, 110 and 200 $\mathrm{kb}$ in size [24]. All KPC-producing isolates harboured bla $a_{\mathrm{KPC}}$-positive plasmids of similar size (approximately $110 \mathrm{~kb})$. Those bla $_{\mathrm{KP} c}$-encoded plasmids were negative for all replicon sequences included in the PBRT panel. However, by the RST method, the KPC-encoding plasmids were positive for the $\mathrm{FII}_{k}$ replicon. Using PCRbased mapping, the plasmids were identified as the pKpQIL type [24]. Both bla $a_{\mathrm{KPC}-2}$ and bla $a_{\mathrm{KPC}-3}$ were part of the transposon Tn4401, isoform a. No transconjugants were obtained from KPC producers. KPC-encoding plasmids were only transferred by transformation of plasmid DNA obtained from isolate $V_{597}$. MICs of the transformant are shown in Table 3.

All of the patients repatriated to the Czech Republic had been hospitalised in intensive care units in the countries they were repatriated from. In two hospitals in the Czech Republic (A6 and A51), isolation precautions were set up immediately after the identification of carbapenem-resistant $K$. pneumoniae isolate.

\section{Discussion}

Carbapenemase-producing enterobacteria seem to be uncommon in the Czech Republic with only three reported cases in the period of 2009 and 2010 and six cases in $2012[1,5,7]$. In 2011, two outbreaks and a few cases of VIM- and KPC-producing $K$. pneumoniae were reported. The $K$. pneumoniae species was the only member of the Enterobacteriaceae family found to produce carbapenemases in that year in the Czech Republic. We believe that the situation is not underestimated because, since the mandatory official guideline was issued by the Ministry of Health in 2012, all carbapenem-resistant enterobacteria have been sent to the NRL for Antibiotics for confirmation of carbapenemase production and epidemiological typing.

The situation of VIM-1-producing $K$. pneumoniae in the hospital $A_{5}$ seems to have been endemic. Even if no epidemiological connection among the isolates could be found (such as hospitalisation on the same ward, use of the same medical procedure or the same medical personnel), most of them were recovered the same time period between May and October 2011 (Table 1, Figure 2). Therefore, the occurrence of these isolates could be considered as an outbreak, but we were not able to identify an index case nor reservoir of the strains. Therefore, our hypothesis was based on molecular typing of the isolates only.

The increasing incidence of KPC-producing K. pneumoniae observed in the Czech Republic in 2011 was initially caused by the repatriation of infected patients from Italy (KPC-3, ST 512 ) and Greece (KPC-2, $\mathrm{ST}_{258}$ ), followed by an outbreak with an $\mathrm{ST}_{512}$ strain in Hospital A41. All isolates showed identical PFGE 
Timeline of successive hospital outbreak of VIM-1-producing Klebsiella pneumoniae isolates in Hospital A5, Czech Republic, $2011(n=5)$

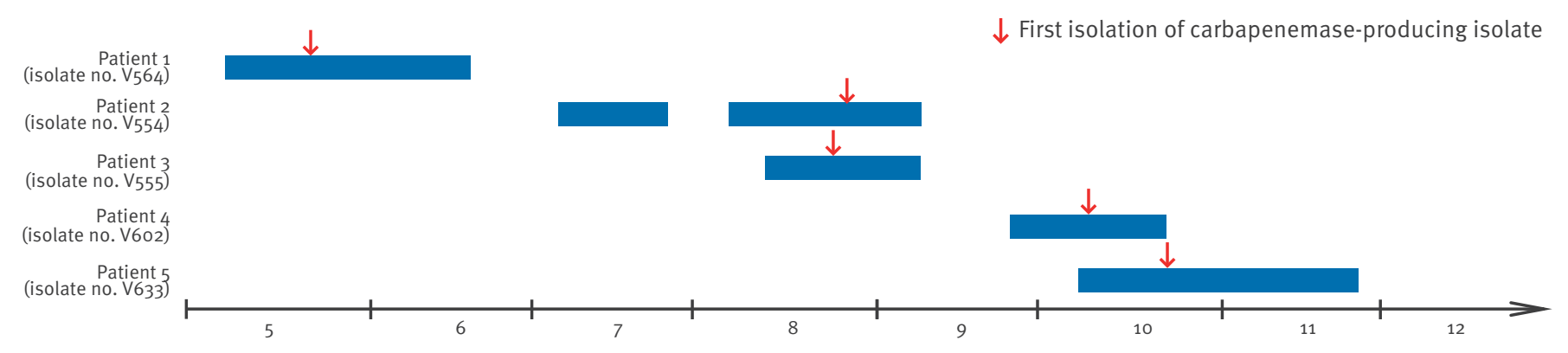

patterns and belonged to ST512, supporting the theory of an outbreak.

This ST is a single locus variant of a widely spread KPC2-producing ST258 clone. ST 12 was first reported from Israel among the isolates producing KPC-3 carbapenemase [28]. All KPC-producing isolates detected in this study were resistant to colistin. Resistance to this drug in KPC-producing $K$. pneumoniae isolates is being described more and more frequently $[29,30]$. Treatment options for infections caused by carbapenemase-producing Enterobacteriaceae are seriously limited until new classes of antibiotics are found; therefore it is necessary to understand the epidemiological principles of the spread of such bacteria and to set up efficient infection control measurements.

It can be assumed that the repatriated patients acquired the carbapenemase-producing Enterobacteriaceae in the foreign countries, since their transport was organised through specialised medical assistance and they were admitted to a Czech hospital without delay. Molecular typing data also confirm this theory. In all of the described patients, screening (such as rectal swab, sputum, urine, wound swab etc.) for identification of carbapenemase-producing Enterobacteriaceae was performed in the intensive care units abroad in a way corresponding to what is recommended in the national guidelines issued by the NRL for Antibiotics [31].

Until mid-2012, there was no official document in the Czech Republic on isolation precautions for patients colonised or infected by carbapenemase-producing Enterobacteriaceae. However, recommendations regarding diagnostic procedures, screening, and specific hygienic measurements were available from the NRL for Antibiotics [31]. Recently, an official guideline for the management of imported cases of carbapenemase-producing Enterobacteriaceae including infection control procedures has been approved and published through a bulletin of the Ministry of Health of the Czech Republic [32]. In this document, screening procedures on medical wards with confirmed occurrence of carbapenemase-producing Enterobacteriaceae are described in detail. The recommended screening is based on rectal swabs collected from patients hospitalised on the same ward or in possible contact with an infected or colonised patient. Other tissues sampled for standard screening in intensive care units (such as sputum, urine, different swabs) should also be tested for carbapenemase-producing Enterobacteriaceae. For patients with suspected or proven carbapenemaseproducing Enterobacteriaceae, strict isolation procedures have to be set up.

In 2012 and 2013, there has not been a further increase in the occurrence of carbapenemase-producing Enterobacteriaceae in the Czech Republic, and only one outbreak (five patients) and four sporadic cases have been noted until mid-2013 (data not shown). An almost similar number of carbapenem-non-susceptible isolates has been sent for confirmation of carbapenemase production from routine laboratories in 2012 as in 2011. Only two imported cases of VIM-1-producing $K$. pneumoniae and NDM-4-producing Enterobacter cloacae have been detected [33]. This situation signalises that the proposed preventive recommendations have been able to stabilise or even decrease the incidence of carbapenemase-producing Enterobacteriaceae in our country.

Czech participants of European Antimicrobial Resistance Surveillance Network in 2011

Vaclava Adamkova, First Faculty of Medicine and University Hospital, Charles University, Prague; Natasa Bartonikova,Bata's Hospital, Zlin; Markyta Bartova, Thomayer's Hospital, Prague; Eva Bendova, Third Faculty of Medicine and University Hospital in Kralovske Vinohrady, Charles University, Prague; Tamara Bergerova, Faculty of Medicine and University Hospital in Plzen, Charles University, Plzen; Zdena Bohunova, Hospital in Liberec, Liberec; Eva Capova, Hospital in Tabor, Tabor, Eva Chmelarova, Institute for Public Health in Ostrava, Ostrava; Marie Dovalova, Novy Jicin; Marian Glasnak, Rudolf's and Stefanie's Hospital in Benesov, Benesov; Marketa Hanslianova, University Hospital in Brno, Brno; Vera Haskova, Institute of Public Health in Kolin, Horovice; Blanka Heinigeova, Hospital in Jindrichuv Hradec, Jindrichuv Hradec; Magdalena Hornikova, Hospital 
in Ceske Budejovice, Ceske Budejovice; Blanka Horova, Hospital in Bulovka, Prague; Jana Janeckova, Hospital in Litomysl, Litomysl; Petr Jezek, Hospital in Pribram, Pribram; Vlastimil Jindrak, Hospital $\mathrm{Na}$ Homolce, Prague; Milan Kolar, Faculty of Medicine and University Hospital, Palacky University, Olomouc; Lenka Kolarova, SYNLAB, Prague; Věra Kůrková, Hospital in Pisek, Pisek; Petr Linhart, Hospital in Havlickuv Brod, Havlickuv Brod; Helena Nedvedova, Hospital in Klatovy, Klatovy; Jana Niemczykova, Institute of Public Health in Ostrava, Havirov; Otakar Nyc, Second Faculty of Medicine and University Hospital in Motol, Charles University, Prague; Vladimir Petkov, Institute for Clinical and Experimental Medicine, Prague; Zora Pokorna, BIOPLUS, Brno; Jan Pomykal, Hospital in Kolin, Kolin; Blanka Puchalkova, Hospital in Karlovy Vary, Karlovy Vary; Miloslava Rumlerova, Institute of Public Health in Kolin, Kladno; Lenka Ryskova, Faculty of Medicine and University Hospital in Hradec Kralove, Hradec Kralove; Josef Scharfen, Hospital in Trutnov, Trutnov; Anna Sekacova, Hospital in Vsetin, Vsetin; Helena Skacaniova, Hospital in Jihlava, Jihlava; Eva Simeckova, Hospital in Strakonice, Strakonice; Martina Sosikova, Hospital in Opava, Opava; Eva Stastna, Hospital in Prerov, Prerov; Alena Steinerova, Military Hospital Praha; Marta Stolbova, Masaryk's Hospital, Usti nad Labem; Renata Tejkalova, Faculty of Medicine and University Hospital of St. Anna, Masaryk's Univerity, Brno; Ladislav Trojan, Hospital in Trebic, Trebic; Hana Typovska, P+R LAB, Sternberk; Eva Uhlirova, NsP, Uherské Hradiste; Eva Vesela, Hospital in Nachod, Nachod; Eva Zalabska, Hospital in Pardubice, Pardubice; Dana Zamazalova, Hospital in Nove Mesto $\mathrm{Na}$ Morave, Nove Mesto Na Morave; Robert Zaruba, Hospital in Most, Most;

\section{Acknowledgements}

This work was supported by the research project grants NT11032-6/2010 from the Ministry of Health of the Czech Republic and by the Charles University Research Fund (project number P36). C.C. Papagiannitsis was supported by the project: „Support of establishment, development, and mobility of quality research teams at the Charles University", registration number CZ.1.07/2.3.00/30.0022, financed by The Education for Competitiveness Operational Programme (ECOP) funded by the ESF and the government budget of the Czech Republic. We thank platform Genotyping of Pathogens and Public Health (Institut Pasteur, Paris, France) for coding MLST alleles and profiles available at www.pasteur.fr/mlst.

\section{Conflict of interest}

None declared.

\section{Authors' contributions}

J.Hrabak and C.C.Papagiannitsis performed molecular typing and prepared the manuscript. V.Studentova was responsible for performing some typing methods. V.Jakubu, M.Fridrichova, H.Zemlickova collected the isolates and the data about the patients from local laboratories and performed phenotypic tests for the detection of resistance mechanisms and determined MICs.

\section{References}

1. Grundmann $\mathrm{H}$, Livermore DM, Giske CG, Canton R, Rossolini GM, Campos J, et al. Carbapenem-non-susceptible Enterobacteriaceae in Europe: conclusions from a meeting of national experts. Euro Surveill. 2010;15(46):pii=19711. Available from: http://www.eurosurveillance.org/ViewArticle. aspx?Articleld $=19711$

PMid:21144429

2. Nordmann P, Naas T, Poirel L. Global spread of carbapenemase-producing Enterobacteriaceae. Emerg Infect Dis. 2011;17(10):1791-8. http://dx.doi.org/10.3201/eid1710.110655 PMid:22000347. PMCid:PMC3310682

3. Cantón R, Akova M, Carmeli Y, Giske CG, Glupczynski $\mathrm{Y}$, Gniadkowski M, et al. Rapid evolution and spread of carbapenemases among Enterobacteriaceae in Europe. Clin Microbiol Infect. 2012;18(5):413-31. http://dx.doi.org/10.1111/j.1469-0691.2012.03821.x PMid:22507109

4. Akova M, Daikos GL, Tzouvelekis L, Carmeli Y. Interventional strategies and current clinical experience with carbapenemase-producing Gram-negative bacteria. Clin Microbiol Infect. 2012;18(5):439-48.

5. Hrabák J, Niemczyková J, Chudáčková E, Fridrichová M, Studentová V, Cervená D, et al. KPC-2-producing Klebsiella pneumoniae isolated from a Czech patient previously hospitalized in Greece and in vivo selection of colistin resistance. Folia Microbiol. 2011;56(4):361-5. http://dx.doi.org/10.1007/s12223-011-0057-6 PMid:21818609

6. Hrabák J, Červená D, Izdebski R, Duljasz W, Gniadkowski $M$, Fridrichová M, et al. Regional spread of Pseudomonas aeruginosa ST357 producing the IMP-7 metallo- $\beta$-lactamase in the Central Europe, J Clin Microbiol. 2011;49(1):474-5. http://dx.doi.org/10.1128/JCM.00684-10 PMid:20980582. PMCid:PMC3020450

7. Hrabák J, Bébrová E, Nyč O, Fridrichová M, Bergerová T, Žemličková H, et al. Záchyt kmene Serratia marcescens současně produkujícího metalo- $\beta$-laktamázu (MBL), širokospektrou $\beta$-laktamázu (ESBL) a dvě $\beta$-laktamázy typu $A m p C$ ve FN Motol. [Isolation of the strain Serratia marcescens producing metallo- $\beta$-lactamase (MBL) and wide acting ESBL and two $\beta$-lactamases AmpC in the University Hospital in Motol]. Zprávy EM. 2009;18(4):139-41. Czech.

8. European Committee on Antimicrobial Susceptibility Testing (EUCAST). Breakpoint tables for interpretation of MICs and zone diameters. Version 1.2 January 2011, Available from: http://www.eucast.org/clinical-breakpoints/

9. Hrabák J, Walková R, Študentová V, Chudáčková E, Bergerová T. Carbapenemase Activity Detection by Matrix-Assisted Laser Desorption/Ionisation Time-of-Flight Mass Spectrometry. I Clin Microbiol. 2011;49(9):3222-7. http://dx.doi.org/10.1128/JCM.00984-11 PMid:21775535. PMCid:PMC3165603

10. Hrabák J, Studentová V, Walková R, Zemlicková H, Jakubu $\mathrm{V}$, Chudackova E, et al. Detection of NDM-1, VIM-1, KPC, OXA-48, and OXA-162 carbapenemases by MALDI-TOF mass spectrometry. J Clin Microbiol. 2012;50(7):2441-3. http://dx.doi.org/10.1128/JCM.01002-12 PMid:22553235. PMCid:PMC3405576

11. Giske CG, Gezelius L, Samuelsen $\emptyset$, Warner M, Sundsfjord A, Woodford N. A sensitive and specific phenotypic assay for detection of metallo- $\beta$-lactamases and KPC in Klebsiella pneumoniae with the use of meropenem disks supplemented with aminophenylboronic acid, dipicolinic acid and cloxacillin. Clin Microbiol Infect. 2011;17(4):552-6. http://dx.doi.org/10.1111/j.1469-0691.2010.03294.x PMid:20597925

12. European Committee on Antimicrobial Susceptibility Testing. Determination of minimum inhibitory concentrations (MICs) of antibacterial agents by broth dilution. Clin Microbiol Infect. 2003;9(8):ix-xv.

http://dx.doi.org/10.1046/j.1469-0691.2003.00790.x

13. Struelens MJ, Rost F, Deplano A, Maas A, Schwam V, Serruys E, et al. Pseudomonas aeruginosa and Enterobacteriaceae bacteremia after biliary endoscopy: an outbreak investigation using DNA macrorestriction analysis. Am J Med. 1993;95(5):489-98 http://dx.doi.org/10.1016/0002-9343(93)90331-I

14. Tenover FC, Arbeit RD, Goering VR, Mickelsen PA, Murray BE, Pershing DH, et al. Interpreting chromosomal DNA restriction patterns produced by pulsed-field gel electrophoresis: criteria for bacterial strain typing. I Clin Microbiol. 1995:33(9):2233-9. PMid:7494007. PMCid:PMC228385.

15. Diancourt L, Passet V, Verhoef I, Grimont PA, Brisse S. Multilocus sequence typing of Klebsiella pneumoniae 
nosocomial isolates. J Clin Microbiol. 2005;43(8):178-82 http://dx.doi.org/10.1128/JCM.43.8.4178-4182.2005 PMid:16081970. PMCid:PMC1233940.

16. Fiett J, Baraniak A, Mrówka A, Fleischer M, Drulis-Kawa Z, Naumiuk $t$, et al. Molecular epidemiology of the acquired metallo- $\beta$-lactamase-producing bacteria in Poland. Antimicrob Agents Chemother. 2006;50(3):880-6.

http://dx.doi.org/10.1128/AAC.50.3.880-886.2006

PMid:16495246. PMCid:PMC1426447.

17. Naas T, Cuzon G, Villegas MV, Lartigue MF, Quinn JP, Nordmann $P$. Genetic structures at the origin of acquisition of the $\beta$-lactamase blaKPC gene. Antimicrob Agents Chemother. 2008;52(4):1257-63. http://dx.doi.org/10.1128/AAC.01451-07 PMid:18227185. PMCid:PMC2292522.

18. Pfeifer Y, Wilharm G, Zander E, Wichelhaus TA, Götting S, Hunfeld KP, et al. Molecular characterization of blaNDM-1 in an Acinetobacter baumannii strain isolated in Germany in 2007. J Antimicrob Chemother. 2011;66(9):1998-2001. http://dx.doi.org/10.1093/jac/dkr256 PMid:21693460

19. Papagiannitsis CC, Giakkoupi P, Vatopoulos AC, Tryfinopoulou K, Miriagou V, Tzouvelekis LS. Emergence of Klebsiella pneumoniae of a novel sequence type (ST383) producing VIM4, KPC-2 and CMY-4 $\beta$-lactamases. Int J Antimicrob Agents. 2010;36(6):573-4.

http://dx.doi.org/10.1016/j.ijantimicag.2010.07.018 PMid:20863669

20. Gniadkowski M, Schneider I, Jungwirth R, Hryniewicz W, Bauernfeind W. Ceftazidime-resistant Enterobacteriaceae isolates from three Polish hospitals: identification of three novel TEM and SHV-5-type extended-spectrum $\beta$-lactamases. Antimicrob Agents Chemother. 1998;42(3):514-20. PMid:9517925. PMCid:PMC105491.

21. Samuelsen $\varnothing$, Naseer U, Tofteland S, Skutlaberg DH, Onken $A$, Hjetland $R$, et al. Emergence of clonally related Klebsiella pneumoniae isolates of sequence type 258 producing plasmidmediated KPC carbapenemase in Norway and Sweden. J Antimicrob Chemother. 2009;63(4):654-8. http://dx.doi.org/10.1093/jac/dkpo18 PMid:19218573

22. Carattoli A, Bertini A, Villa L, Falbo V, Hopkins KL, Threlfall EJ. Identification of plasmids by PCR-based replicon typing. I Microbiol Methods. 2005;63(3):219-28. http://dx.doi.org/10.1016/j.mimet.2005.03.018 PMid:15935499

23. Villa L, García-Fernández A, Fortini D, Carattoli A. Replicon sequence typing of IncF plasmids carrying virulence and resistance determinants. J Antimicrob Chemother. 2010;65(12):2518-29.

http://dx.doi.org/10.1093/jac/dkq347 PMid:20935300

24. Baraniak A, Grabowska A, Izdebski R, Fiett J, Herda M, Bojarska K, et al. Molecular Characteristics of KPC-Producing Enterobacteriaceae at the Early Stage of Their Dissemination in Poland, 2008-2009. Antimicrob Agents Chemother. 2011;55(12):5493-9.

http://dx.doi.org/10.1128/AAC.05118-11

PMid:21930889. PMCid:PMC3232751.

25. Damjanova I, Tóth A, Pászti J, Hajbel-Vékony G, Jakab M, Berta J, et al. Expansion and countrywide dissemination of ST11, ST15 and ST147 ciprofloxacin-resistant CTX-M-15-type $\beta$-lactamaseproducing Klebsiella pneumoniae epidemic clones in Hungary in 2005 - the new 'MRSAs'?. J Antimicrob Chemother. 2008;62(5):978-85.

http://dx.doi.org/10.1093/jac/dkn287 PMid:18667450

26. Empel J, Hrabák J, Kozińska A, Bergerová T, Urbášková P, KernZdanowicz I, et al. DHA-1-producing Klebsiella pneumoniae in a teaching hospital in the Czech Republic. Microb Drug Resist. 2010;16(4):291-295.

http://dx.doi.org/10.1089/mdr.2010.0030

PMid:20624093

27. Samuelsen $\varnothing$, Toleman MA, Hasseltvedt V, Fuursted K, Leegaard TM, Walsh TR, et al. Molecular characterization of VIM-producing Klebsiella pneumoniae from Scandinavia reveals genetic relatedness with international clonal complexes encoding transferable multidrug resistance. Clin Microbiol Infect. 2011;17(12):1811-6.

http://dx.doi.org/10.1111/j.1469-0691.2011.03532.x PMid:21595797

28. Warburg G, Hidalgo-Grass C, Partridge SR, Tolmansky ME, Temper V, Moses AE, et al. A carbapenem-resistant Klebsiella pneumoniae epidemic clone in Jerusalem: sequence type 512 carrying a plasmid encoding aac(6')-Ib. J Antimicrob Chemother. 2012;67(4):898-901.

http://dx.doi.org/10.1093/jac/dkr552

PMid:22287232
29. Kontopoulou K, Protonotariou E, Vasilakos K, Kriti M, Koteli A, Antoniadou E, et al. Hospital outbreak caused by Klebsiella pneumoniae producing $\mathrm{KPC}-2$ beta-lactamase resistant to colistin. J Hospit Infect. 2010;76(1):70-3. http://dx.doi.org/10.1016/j.jhin.2010.03.021 PMid:20705205

30. Tóth A, Damjanova I, Puskás E, Jánvári L, Farkas M, Dobák $A$, et al. Emergence of a colistin-resistant KPC-2-producing Klebsiella pneumoniae ST258 clone in Hungary. Eur I Clin Microbiol Infect Dis. 2010;29(7):765-9. http://dx.doi.org/10.1007/s10096-010-0921-3 PMid:20401676

31. Hrabák J, Urbášková P, Bergerová T, Žemličková H. Komentár̆ k polskému doporučení postupu při výskytu kmenů Enterobacteriaceae produkujících karbapenemázy typu KPC ve zdravotnických zařízeních. [Comments on the Recommendations on the steps to be taken in case of the emergence of KPC carbapenemase-producing strains of Enterobacteriaceae in healthcare settings in Poland]. Zprávy EM. 2010;19(6-7):196-198. Czech.

32. Ministry of Health of the Czech Republic. Metodický pokyn ke kontrole výskytu importovaných případů kolonizace a/ nebo infekce enterobakteriemi produkujícími karbapenemázu. [Guideline for the control of spread of carbapenemaseproducing bacteria that infect or colonize patients repatriated from a foreign country]. Bulletin of the Ministry of Health of the Czech Republic. 2012;8:10-9. Czech.

33. Papagiannitsis CC, Studentova V, Chudackova E, Bergerova T, Hrabák J, Raděj J, et al. Identification of a New Delhi Metallo$\beta$-lactamase-4 (NDM-4)-producing Enterobacter cloacae from a Czech patient previously hospitalized in Sri Lanka. Folia Microbiol. 2013;58(6):547-9. http://dx.doi.org/10.1007/s12223-013-0247-5 PMid:23546833 